\title{
Egyptian revolution as source in printing fashion designs
}

\author{
Manal Mohamady Taha Eladwy ${ }^{1}$, Maha Mohamady Taha Eladwi \\ ${ }^{1}$ Faculty of Specific Education, El-Fayoum Uni., El-Fayoum, Egypt \\ ${ }^{2}$ Faculty of Women, Ain Shams Uni., Cairo, Egypt
}

\section{Email address:}

manalaladawy@yahoo.com(M. M. T. Eladwy),mamota74@yahoo.com(M. M. T. Eladwi)

\section{To cite this article:}

Manal Mohamady Taha Eladwy, Maha Mohamady Taha Eladwi. Egyptian Revolution as Source in Printing Fashion Designs. Humanities and Social Sciences. Vol. 1, No. 1, 2013, pp. 11-20. doi: 10.11648/j.hss.20130101.13

\begin{abstract}
Welcome to our revolution. It's the same perpetual bewilderment between faith and unbelief, action and inertia, perseverance and despair; as always, victory will come only to the believers, to the dreamers, to those willing to bare their breast to the fire, not to die but to prevail with their bodies and remain steadfast. Protesters evoke Egyptian folk art symbols to express revolution. The research focus on symbols used in revolution as writing on walls, drawing on walls, rural scarf, rural earring, copper ring, Arabic writings, and National symbols. The research will study the effect of Egyptian folk art elements on the revolution phenomenon. Design new printing design and clothing design inspired from revolution phenomenon and reflect Egyptian loyalty to folk art. And, will use the elements of printing and clothing in designs to make the new trends in fashion and emphasis on Egyptian identity.
\end{abstract}

Keywords: Egyptian Revolution, Printing Design, Fashion Design

\section{Introduction}

The Egyptian revolution came to declare the end of history and the beginning of a new history; people have become the master himself.

Return national spirit and national cultural in the Arab world will pave the way for the return of the spirit of nationalism and national culture and thus revive the Arab Unionist project. (1)

Protesters evoke Egyptian folk art symbols to express revolution. The research focus on symbols used in revolution as writing on walls, drawing on walls, rural scarf, rural earring, copper ring, Arabic writings, and National symbols.

From this phenomenon, the researcher will be focusing on these elements to inspired modern printing clothing designs. For this reason, the research mentions the Egyptian revaluation development from Egyptian ancient.

\subsection{History Study}

Biopi second last king of the Sixth Dynasty and long reign of four and ninety years and was the longest period in history for the governor is that they almost aging until the State has an aging old and swept the country after him Revolution where looting and panic spread and tip water flood and if famine damaged people very much. It was the first revolution in history ancient Egyptian.(2) Focusing on popular protest and mobilization in Egypt's 1919, 1952, and 2011 revolutions, I focus on the internal dynamics of, and discontinuities between, each of these revolutions, characterizing them as nationalist, passive, and popular, respectively.(3)

Egypt's own 1919 and 1952 revolutions, but do these vivid comparisons conceal more than they reveal? Indeed, one could argue that one of the most striking aspects of the contemporary media discussions surrounding Mubarak's Egypt is the absence of any real sense of history. It is not enough to fill this void with rhetorical comparisons and poetic license.(3)

The Egyptian Revolution of 1919 was a countrywide revolution against the British occupation of Egypt and Sudan. It was carried out by Egyptians and Sudanese from different walks of life in the wake of the British-ordered exile of revolutionary leader Saad Zaghlul, and other members of the Wafd Party in 1919. The revolution led to Britain's recognition of Egyptian independence in 1922, and the implementation of a new constitution in 1923.(4)

And, The role of women has emerged Egyptian national issues where the exit of Egyptian women at the forefront of the public to participate in the 1919 revolution and the martyrdom of one of them is a clear indication on their involvement in the Egyptian national movement.(5)

Britain, however, refused to recognize full Egyptian 
sovereignty over Sudan, or to withdraw its forces from the Suez Canal Zone, factors that would continue to sour Anglo-Egyptian relations in the decades leading up to the Egyptian Revolution of 1952.(4)

After the revolution of July 23, 1952 established the concept of women's participation in all spheres of political, economic and social, has won the right to vote and stand for election in 1956.(5)

No matter how it unfolds, the Egyptian revolution will go down in the history books as a defining moment in the 21 st century. Millions of Egyptians brought down one of the world's most repressive regimes, that of the US-backed Hosni Mubarak, in just 18 days. Their bravery, perseverance, and tactfulness in the face of the regime's brutal crackdown not only triggered uprisings across the Arab world but inspired and influenced protesters against government austerity in the US, Spain, Portugal, and Greece. Despite the fact that it is only a few months old, it's important to begin piecing together a people's history of the revolution to convey what happened and how it happened so that the lessons from this critical struggle can be disseminated.(6)

And, the participation of women in order to defend national issues, in order to pay the injustice that perch on the emergence of Egyptians broking, and for the search for justice not only for women but for all Egyptians. We have seen rare models for girls and women shouting fall of the regime, and to defend their ideas and attitudes, and speaking to masses with unrivaled enthusiasm, and helping to provide food and drink.(7) \& (8)

The research will study the effect of Egyptian folk art and ancient Egyptian art elements on the revolution phenomenon. Design new printing design and clothing design inspired from Egyptian revolution phenomenon as a source of inspiration in both structural \& decorative designs. And, will use the elements of printing and clothing in designs to make the new trends in fashion to emphasis on Egyptian identity.

\section{Experimental Work}

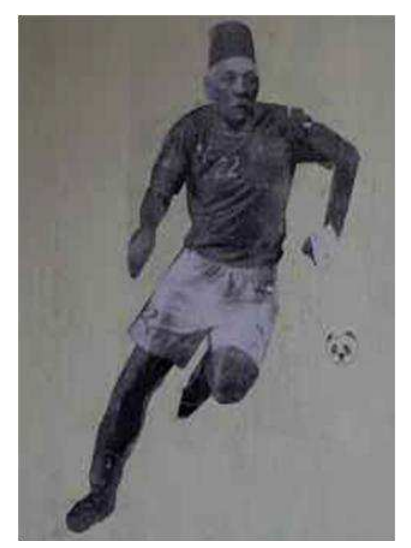

Fig (1) The Revolution Scored a Goal! (Saad Zaghloul, independence leader of 1919 revolution wearing star footballer Abou Treika's jersey.) Sad Panda El Marghani, Heliopolis photo: Maya Gowaily.(9)
Egyptian revolution is more than a simple mania for Egyptian protesters. It is not enough to copy famous Egyptian nation forms- real artists must "re- create" them in the cauldron of their own sensibility and in the context of their times, or must give them an appearance of renewed vitality, a function other than the purpose for which they were originally intended as shown as in figure [1], The Revolution Scored a Goal! (Saad Zaghloul, independence leader of 1919 revolution wearing star footballer AboTreika's jersey.).(9)

The protesters mixed between the old symbols and our revolution symbols to reflect relationship between themselves and Egyptian history. Young Egyptian artist's draws on many sources: on one hand, ancient originals that were copied or adapted with varying degrees of fidelity depending on the happen; on the other hand from forms derived from earlier Egyptian production dating from the National symbols.

The art analysis of some revolution designs that influenced by Famous Faces, Arabic lines, Famous scenes ancient Egyptian and our revolution, or national colours, and painted scenes.

\subsection{Revaluation Symbols Inspirations}

\subsubsection{Faces}

Figure [2-a] Ernesto "Che" Guevara, commonly known as el Che or simply Che, was an Argentine Marxist revolutionary, physician, author, guerrilla leader, diplomat, and military theorist. A major figure of the Cuban Revolution, his stylized visage has become a ubiquitous countercultural symbol of rebellion and global insignia within popular culture.(10)

Figure [2-b] shows recreated Guevara picture inspired directly from the Egyptian Pharaoh Tut Ankh Amen with Keizer artist. Keizer needs mixing between Guevara as a symbol of revolution for world youth and Egyptian symbol young pharaoh Tut Ankh Amen to reflect influence the Egyptian youth by Egyptian ancient history and related by revolutions history.

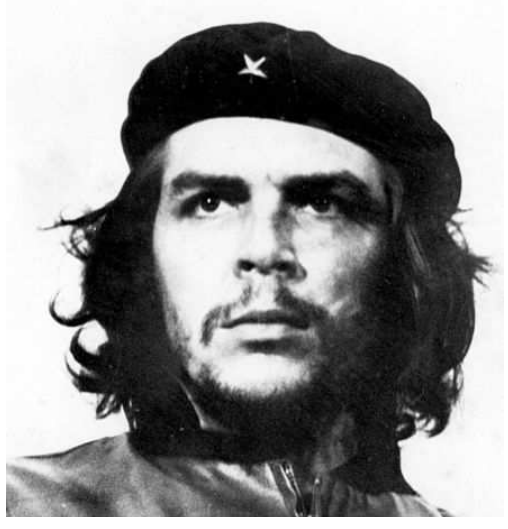

Fig [2 a] Ernesto "Che" Guevara. (10) 


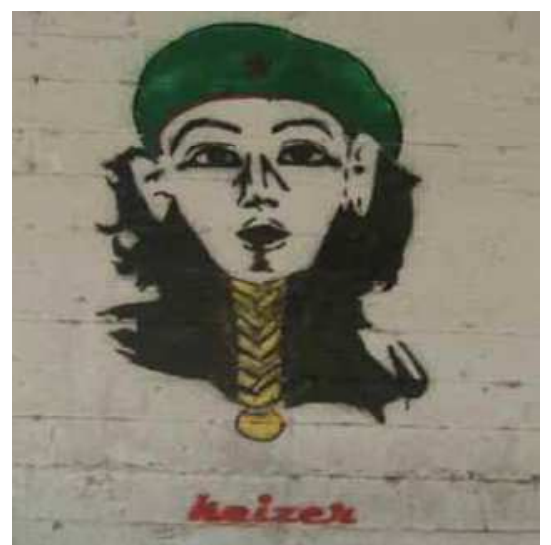

Fig [2 b] Pharaoh Guevara, Keizer, Gezireh, Zamalek, photo: Maya Gowaily. (9)

Figure [3-a] Akhenaten first attempted to impose uniformity in the Egyptian religions in the era of the Pharaohs and how is Palace Worship the one God is Aton as religion revolution.

Figure [3-b] Sheikh Emad Effat cited in the events of the Council of Ministers on Friday, December 16, 2011 after being shot. He said:"The air Tahrir Square is the best for myself from Air Kaaba".(9) Revolution artist draw Sheikh Emad Effat in Akhenaten picture because the both made revolution in religion concepts from point of protesters view.

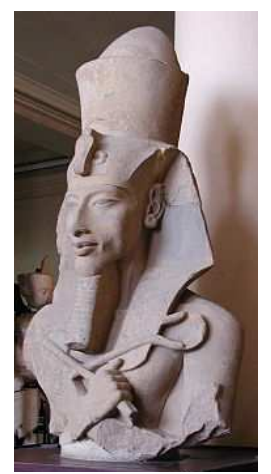

Fig [3-a] Akhenaten.

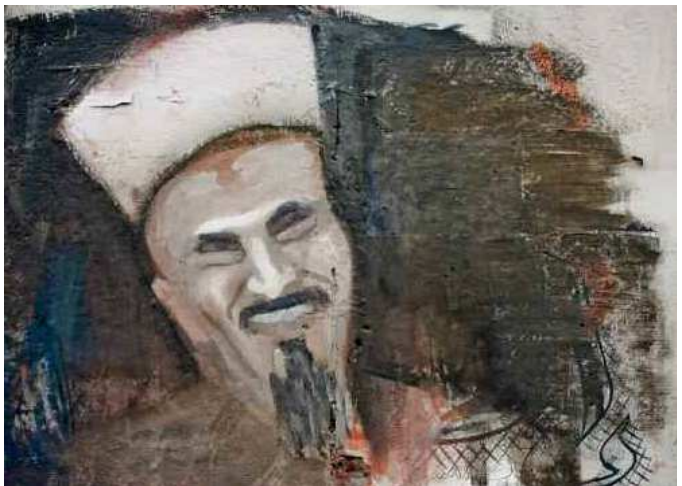

Fig [3-b] Sheikh Emad Effat, Tahrir Square, photo: Maya Gowaily.(9)

Figure [4-a] shown Guy Fawkes mask. V for Vendetta is a 2005 political thriller film. The film had been seen by many political groups as an allegory of oppression by government; libertarians and anarchists have used it to promote their beliefs. Activists belonging to the group Anonymous use the same Guy Fawkes mask popularized by the film when they appear in public at numerous highprofile events, emulating one of its key scenes. These masks have been seen at Occupy movement events and Egyptian revolution.(11)

Figure [4-b], show young Pharaoh Tut Ankh Amen with famous cover wear V for Vendetta mask. Zeft Egyptian artist draw Guy Fawkes mask to reflect anarchists in Egypt by corporation with Tut Ankh Amen Mask. Alpha

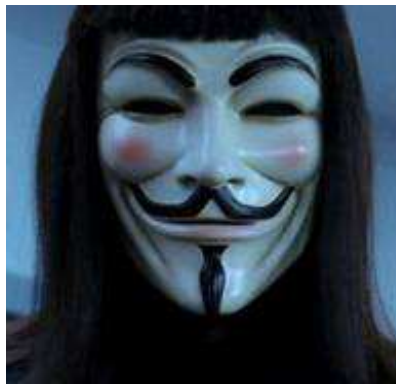

Fig [4-a] Guy Fawkes mask from V for Vendetta film.

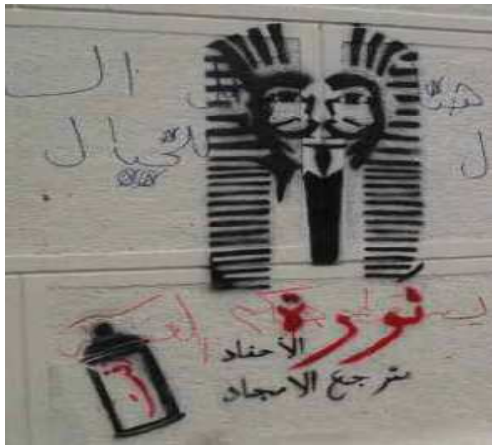

Fig [4-b] Our Descendants' Revolution will Bring Back Our Former Glory, Zeft, The Cabinet, photo: Maya Gowaily.(9)

Figure [5] shown young Egyptian artist draw eyes from Egyptian ancient to give us feeling live eyes as symbol truth front to liars politics. And, write by Arabic language liars (kazaboen) with army caps. He draw close mouse reflect silence with liars.

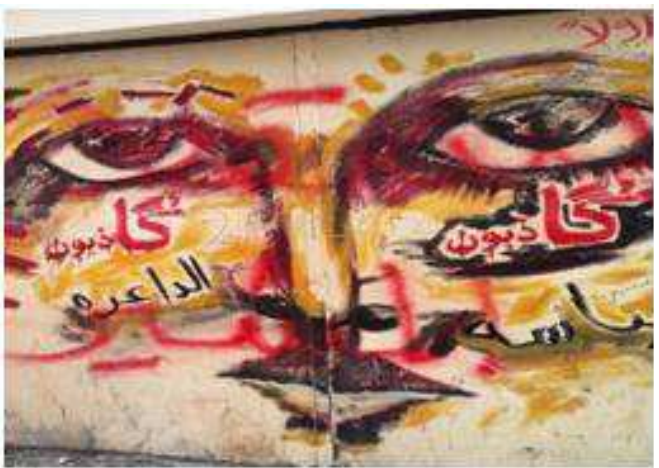

Fig [5] The Martyr First Liars Prostitution Politics, Mohamed Mahmoud St., Downtown, photo: Maya Gowaily.(9) 


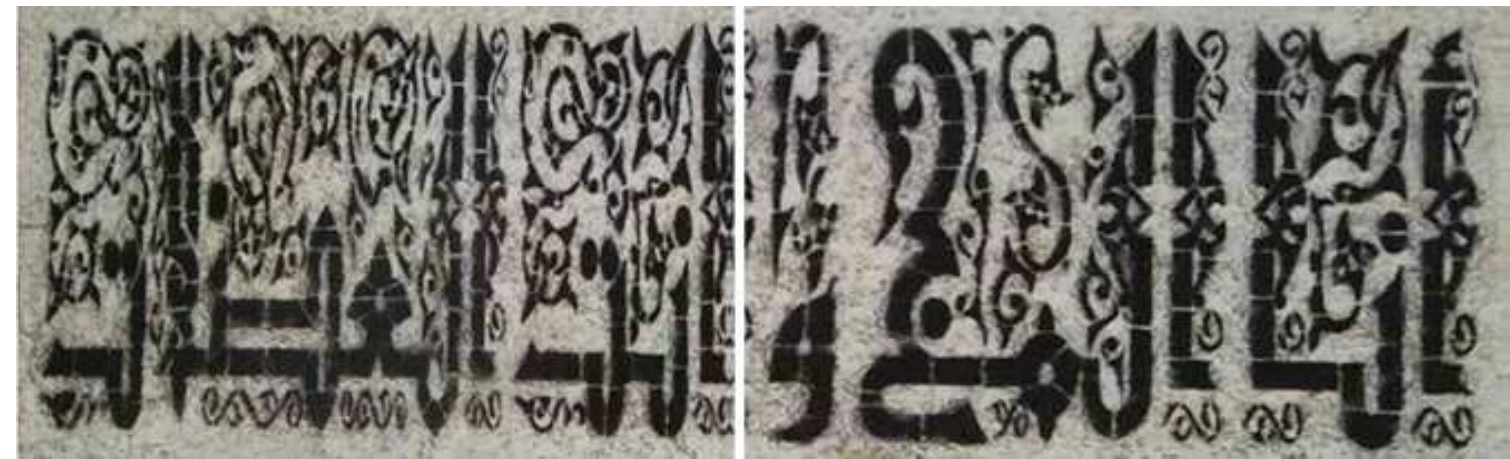

Fig [6] I'm the Brains and You're the Brawn by Arab Kofi line, Mohamed Mahmoud St., Downtown, photo: Maya Gowaily.(9)
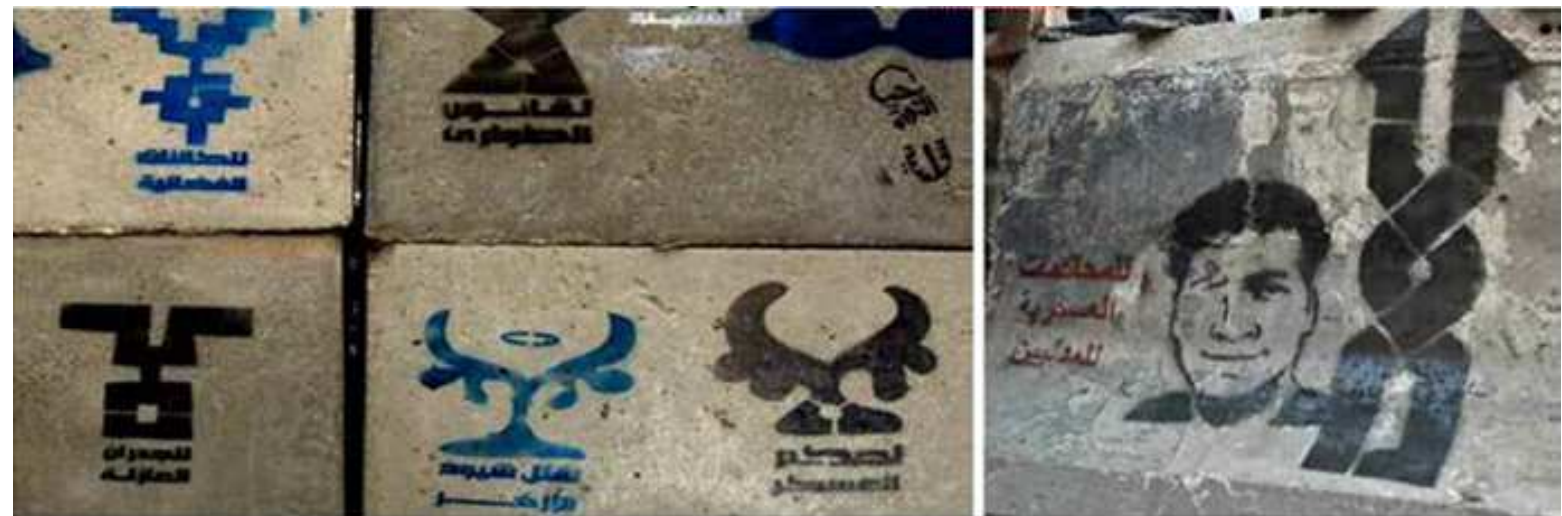

Fig [7] No Extra-Terrestrials. No Emergency Law. Long Live the Revolution. Non-Violent. No Separation Walls. No Killing Azhar Sheikhs. No Military Trials for Civilians. Fahmi St., Downtown, photo: Maya Gowaily and Omar Kamel.(9)

\subsubsection{Arabic Lines}

Figure [6] shows recreated production inspired directly from the Islamic lines. The artist write "I'm the Brains and You're the Brawn" by Arab Kofi line to reflect Egyptian loyalty to folk art.

Figure [7] shows Protesters artist write revolution slogans by different types from Arab Kofi Line. The artist wanted making attention to people by usage Islamic lines.

\subsubsection{Women in Revaluation}

Figure [8] shows Mural inspired from famous Egyptian ancient reflect the woman act in Egyptian revolution. The artist draw brave women walk to back in funeral as symbol to funerals that killed in Egyptian revolution.

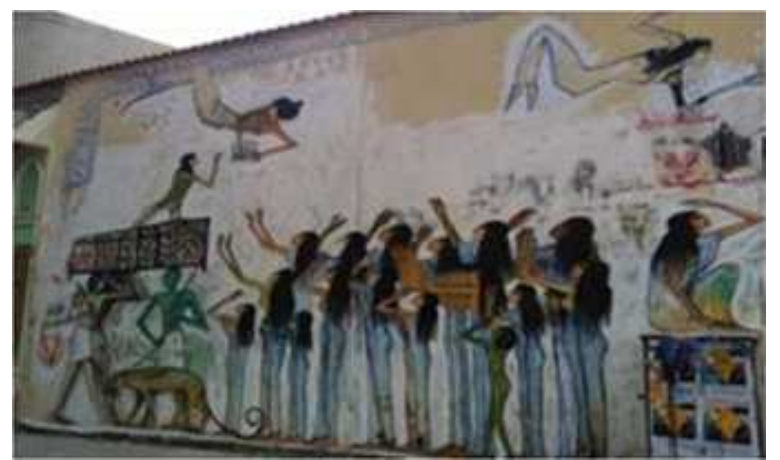

Fig [8] Mohamed Mahmoud Mural, Alaa Awad, Mohamed Mahmoud St., Downtown, photo: Maya Gowaily.(9)
Figure [9] shows Mural inspired from Egyptian ancient drawn women fight and up stairs to arrive to high aim. Alaa Awad influenced by women participation in Tahrir Square.

Figure [10] shows Mural by Alaa Awad artist draw group of women walked beside each other's covered heads with wearing like rural woman, and carrying in their hands papers and sticks. They had leader and heading to pharaoh like protesters in revolution with the same courage and strongest.

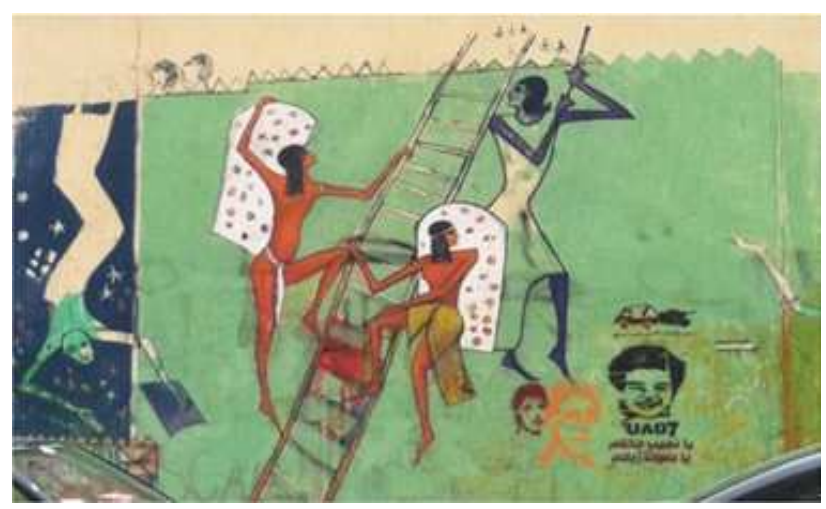

Fig [9] Mohamed Mahmoud Mural, Alaa Awad, Mohamed Mahmoud St., Downtown. 




Fig [10] Mohamed Mahmoud Mural, Alaa Awad, Mohamed Mahmoud St., Downtown, photo: Maya Gowaily.(9)

\subsubsection{Egyptian Ancient Scene Inspired in Revaluation}

Figure [11] shows Mural contained different symbols from Egyptian ancient in big man as enemy warp by robes, some faces, and writing words. The big man expresses about old regime must trial like the Hittite during the reign Ramses II in Egyptian ancient.

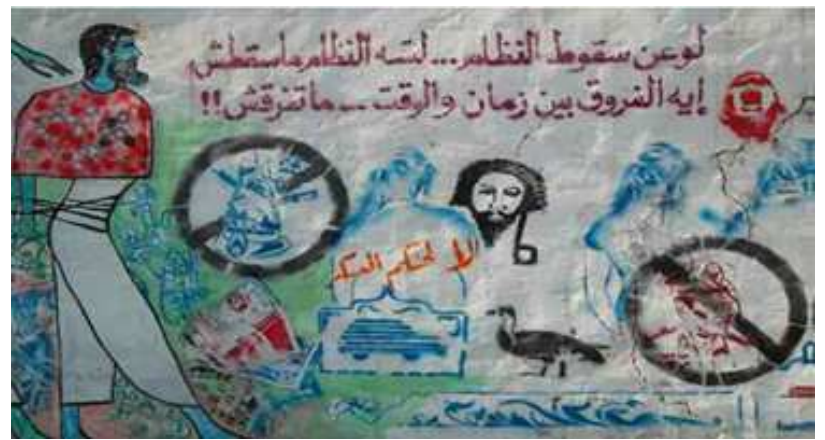

Fig [11] If It's About the Fall of the Regime, It Hasn't Fallen Yet. What's the Differences between Then and Now? Nothing. Ammar Abu Bakr \& Alaa Awad, Champollion St., Downtown, photo: Maggie Osama.(9)

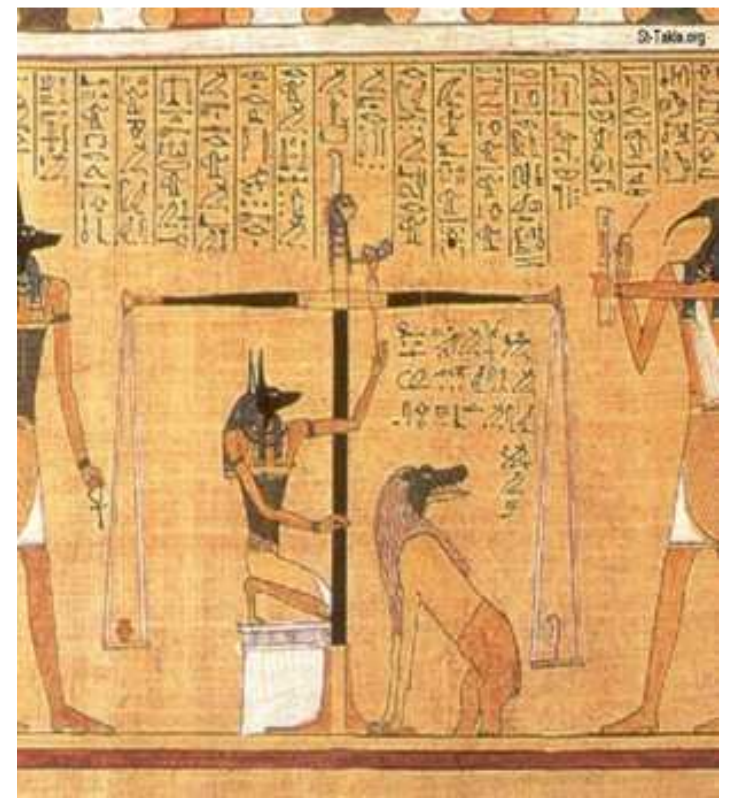

Fig [12-a] Panel Account Anubis God of the dead

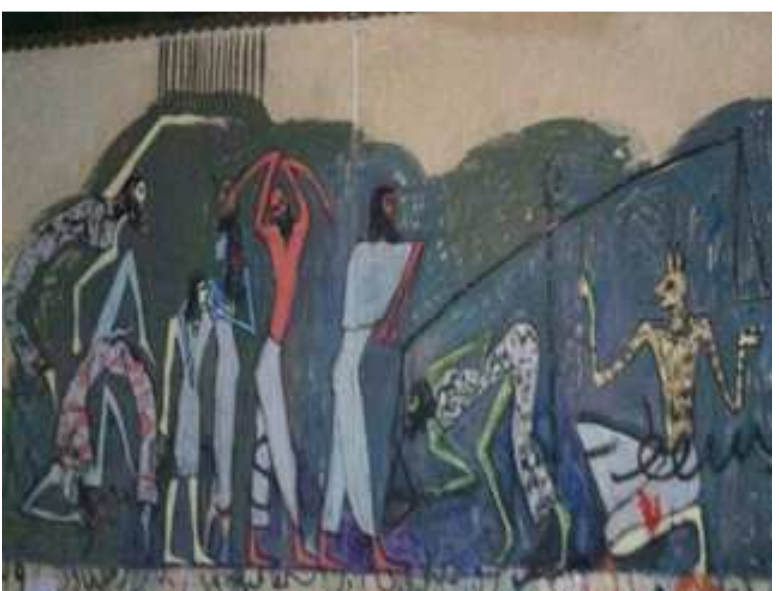

Fig [12-b] Mural from AUC wall in Tahrir Square reflect the unfair trial and unbalance of justice.

Figure [12-a] shows Panel Account Anubis God of the dead from Egyptian ancient.

Figure [12-b] shows Mural from AUC wall in Tahrir Square reflect the unfair trial and unbalance of justice. And, the people in mural like Hittite and one body play in the scale of justice. The artist reflects unfair trial in our revolution usage a famous Mural.

\subsubsection{Photography Scene}

Figure [13] saw Bridge Kasr El-Nil confrontations pedicle between peaceful protesters and the Central Security Forces on January 28 in what is known collecting anger and that played a major role in the overthrow of the Egyptian regime where launched teams Central Security tear gas at the protesters and sprayed water on them, vehicles have also Central Security to kill them and had ended by confrontations protesters to enter Tahrir Square. Statue of Saad Zaghloul, in front of the Egyptian Opera House was witness on what happened in this battle. Modern history will remember this battle, "the battle of Qasr al-Nil Bridge". This time was not a battle against the Zionists and the British, but was with the new occupier soldiers perched on our chests. We fought with our money. And the weapons of our children from the same people.(12)

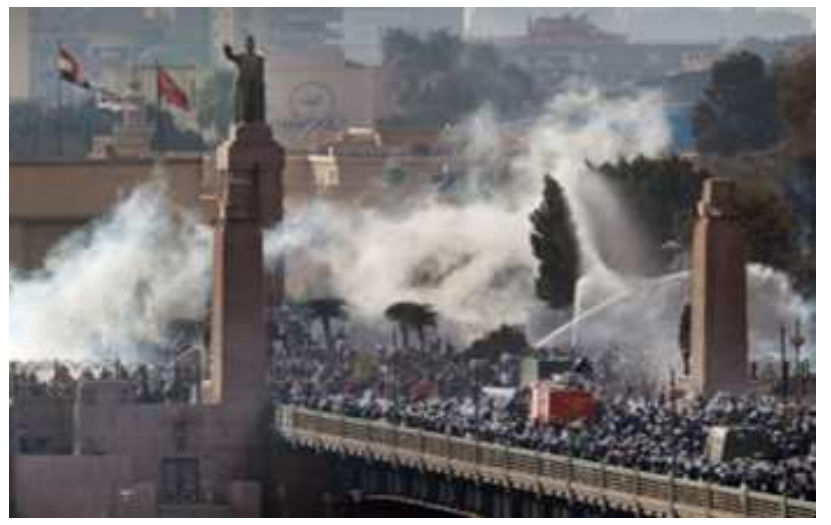

Fig [13] Scene of the 2011 revolution; image from Getty Images / Peter Macdiarmid.(3) 
Figure [14] shows Egyptian tank man is the title of an anonymous young man who became famous worldwide when he was filmed during the January 25 revolution in Egypt in 2011.(13) Famous video which depicts the situation, plucked a photojournalist named Mostafa Fathy, works radio Hority, in Egypt. Position has filmed from of his office in the Qasr al-Aini Street.(3) The pictures taken him, and widely spread, has taken another photojournalist named Tariq Gaed, works Al-Masri al-Youm, Egypt.

\subsubsection{Accessories}

Figure [15] shows different accessories usage to express on revolution. Figure [15-a] rural scarf was called by revolutionaries to express his revolution identity. Figure [15-b,c,d] reflect Arabic lines with folk art in copper accessories from necklace, earring, and ring. Figure [15-e,f] show bracelet and necklace used sliver and beads by national colours (red- white- black)

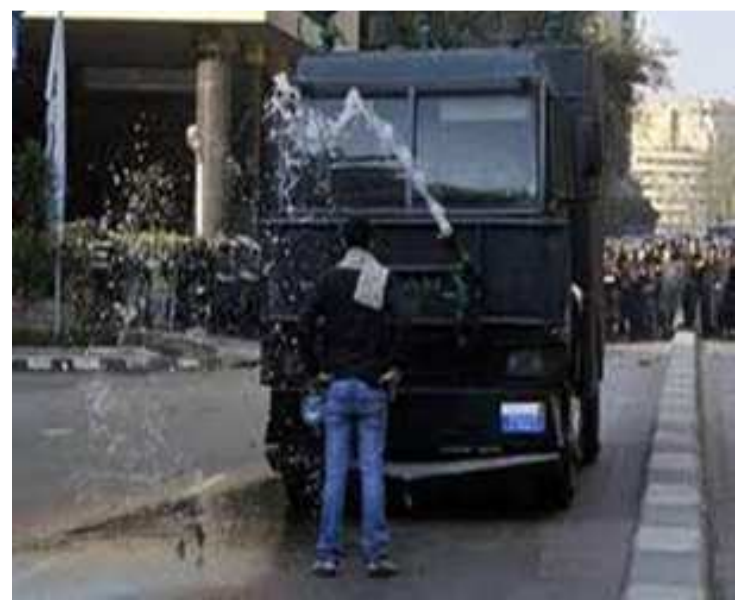

Fig [14] Egyptian tank man, photo by Tariq Gaed, photojournalist, AlMasri al-Youm, Egypt.(13)

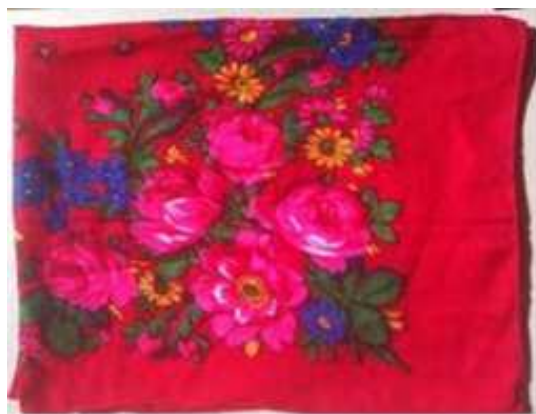

[a]

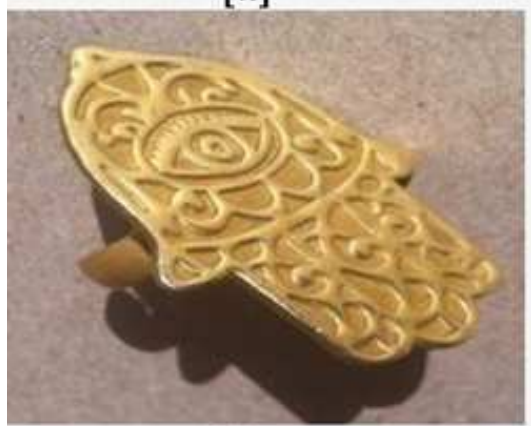

[d]

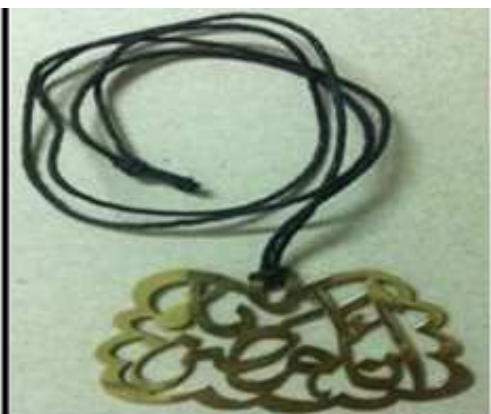

[b]

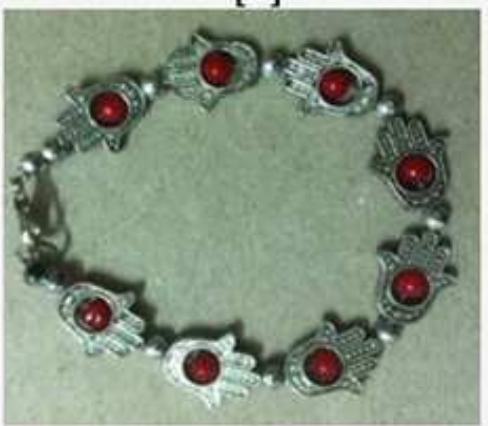

[e]

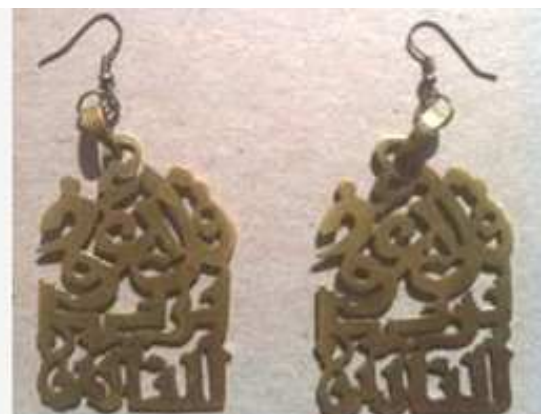

[c]

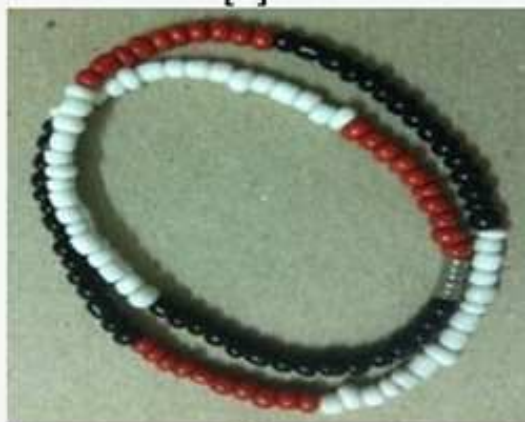

[f]

Fig [15] Different accessories wear by protesters in Egyptian revolution Alpha

\section{Results and Discussions}

From study analysis to some Egyptian revolution works and influenced by Egyptian ancient and revolution symbols. The researcher makes modern Egyptian Printing clothing designs from influenced by Egyptian revolution to make new trends in fashion designs. There are printing and clothing designs elements repeated from work to work in Revolution. We will remember in the following:

- Mix between The Egyptian ancient faces and famous revolution faces and the.

- Usage the Arabic lines to write the revolution slogans.
- Calling women scene from history to reflect the women act in Egyptian revolution. And, the history justice situation to reflect current situation.

- Much more usage layers fabrics in dress at all to body protect.

- Used dramatic natural lines to express about moving and freedom.

- Almost colours are shiny and pure and national colours (red- white- black).

- Many bracelets in arms, necklace .And usage veils, tassels, and flaps.

In the following six designs inspirited from above elements to make modern Egyptian printing clothing designs:- 


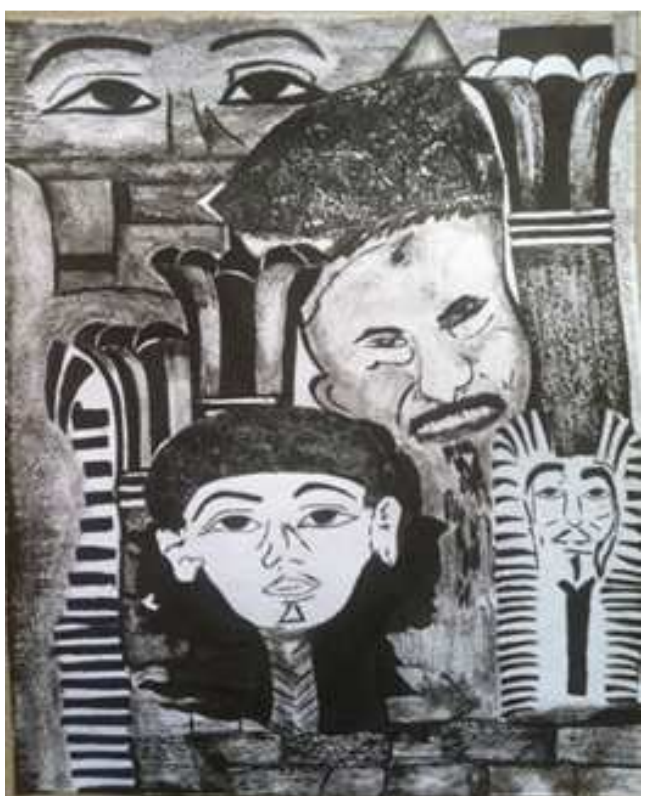

Figure (16-a) inspired decorative design (textile printing design)

In this design the decorative units used fig. [2-b, 3-b, 4-b] alternate between the faces copied and adapted from ancient Egyptian and columns and capital, jars, head of pharaoh, and ruinous of old temple in trial to recreate these elements together in novel usage of decorative units. Repetition of the head of pharaoh refers to the continuity and longevity for revolution symbol.

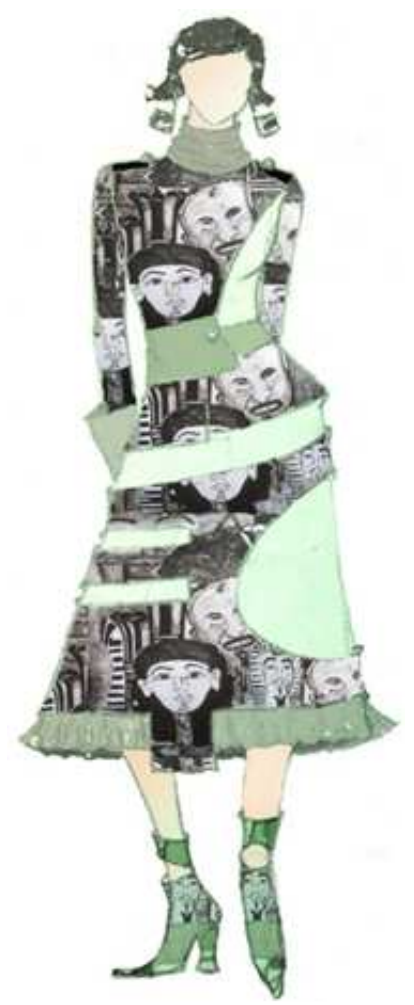

Figure (16-b) inspired structural design (fashion design)

The design contain jacket and skirt inspiration from Egyptian rural clothing by usage cover in upper part and gather in lower part. The main inspiration source is columns and capital. The garment may be divided into many parts, to give us feeling eye restful between decorative parts and solid parts. Curve lines in design make movement and activity to express about revolution with horizontal lines. Usage gradation colours from white to black for give design eldest.

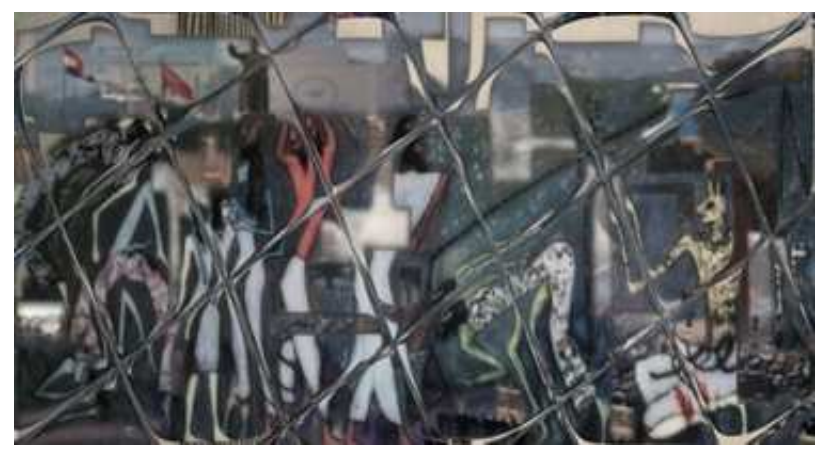

Figure (17-a) inspired decorative design (textile printing design)

In this design merge fig.[12-b] and fig. [13] as symbol inequity in past that led his Qasr al-Nil bridge crossing to the future. The filter used to imagine the past from Egyptian ancient it for the present and future. But, Egyptian flag appear in the back to national confirm. And, appear Arabic line in design right (down).

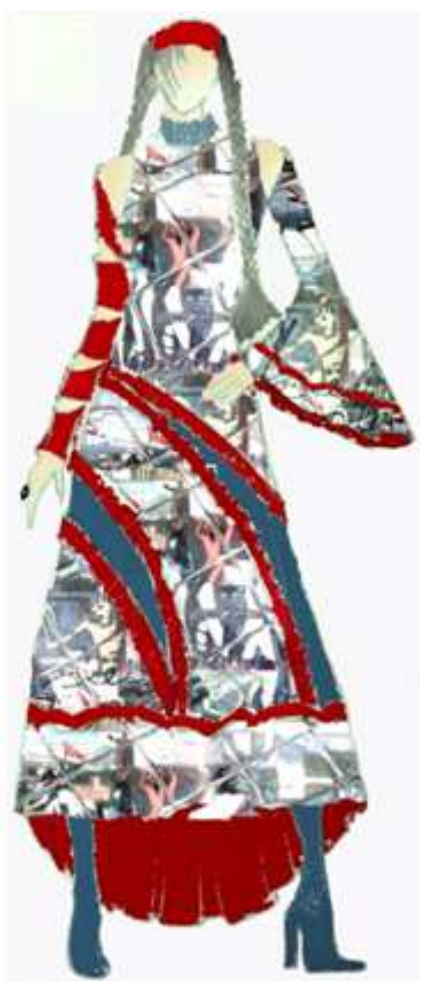

Figure (17-b) inspired structural design (fashion design)

In this design inspired from rural women dress tight in upper and wide in lower dress. See curve lines in collar, sleeves, dress skirt, and edge. The decorative design distribute in all dress with cutting it by red gathers and solid turquoise fabric. The unbalance design increase feeling the movement freedom and the unity between dress, 
shoes, and cover head give feeling completeness.

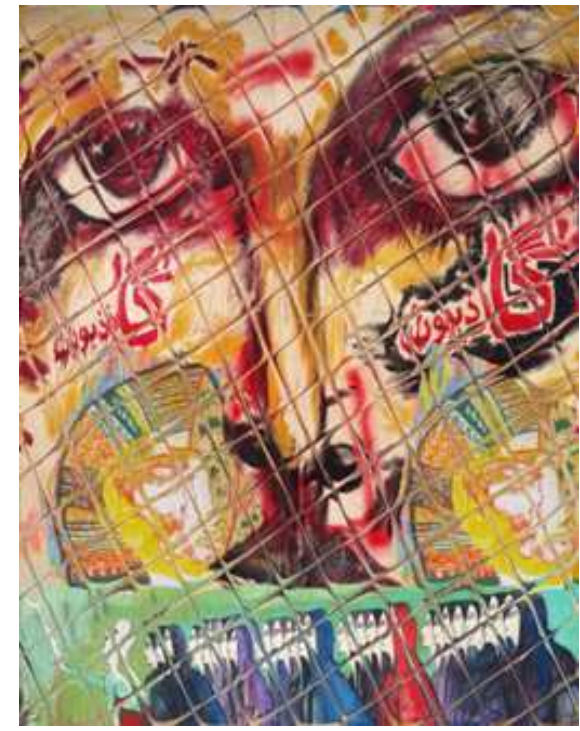

Figure (18-a) inspired decorative design (textile printing design)

The design basically consists of complete face with its eyes along with ancient Egyptian women in lower part from fig. [5] and fig. [8]. The space between eyes to mouse contains Arabic line (kazabon) and girl Egyptian ancient. The filter made the sense of a type of motion by net from right and lift diagonal lines. This distribution of elements with pure and hot colours gives gradation in all design and gives the sense of history and refers to the richness of component.

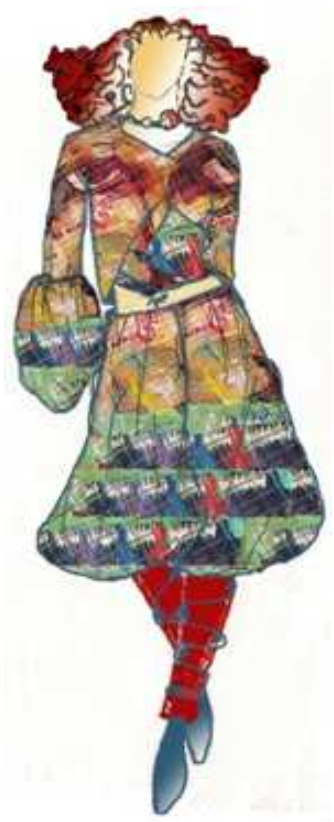

Figure (18-b) inspired structural design (fashion design)

This design contains blouse and trousers inspired from Egyptian fish man costume. The eyes from decorative design distributed in tight blouse and Arabic lines with girl Egyptian ancient in upper trousers. The lower part from decorative design repeated in wide part in sleeve and trousers to give feeling of dominance the women in revolution. The colours grade from yellow, red, and blue to give consistent steps.

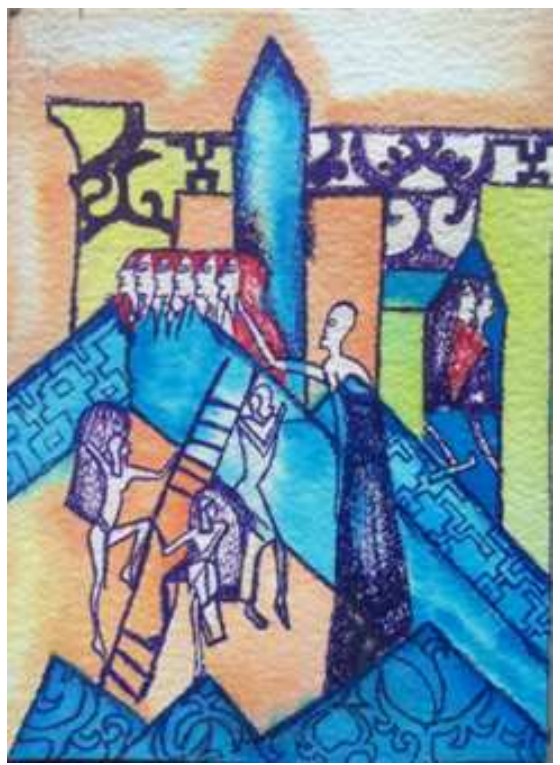

Figure (19-a) inspired decorative design (textile printing design)

Pharaoh, obelisk, pyramid, temple wall, Arabic lines from fig.[7], women on stairs in fig. [9], and group of women in fig. [10], gathered in this design in trial to create a type of harmony among the different monuments that has sharp edges and bended and diagonal lines. The repetition the different types of Arabic lines refer to the welling to make balance with other component. The bright colours of the design reflect the dynamic atmosphere that suitable to women's customs.

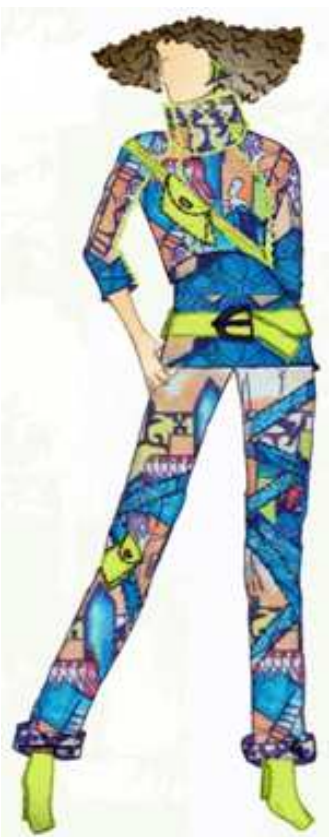

Figure (19-b) inspired structural design (fashion design) 
The design contains blouse and trousers influenced by obelisk in decorative design. And, usage Arabic lines in diagonal cuts in trousers, trousers edge and in body under blouse. The diagonal lines of raglan sleeve of blouse draw attention to decorative design. The bright green colour used in pockets, belt, sewing stitches and shoes. The design emphasis feminine inspirit from women Egyptian ancient.

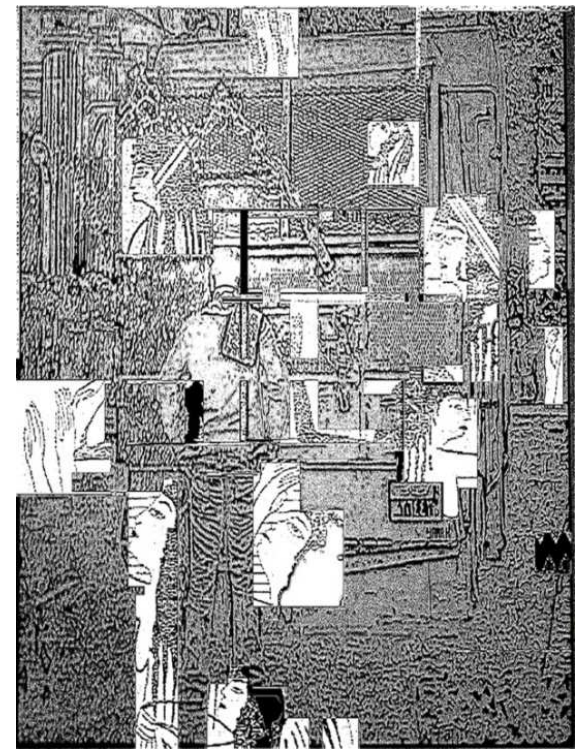

Figure (20-a) inspired decorative design (textile printing design)

The design elements include women Egyptian ancient from fig. [8] and Egyptian tank man from fig. [14]. The tank man is in the center of the design to make balance and the women cut design reflect the real video from revolution when man stop front tank and women scream:"brave". The filter made harmony between women and tank man to complete each other. The gradation white colour to black colour give feeling depth of history from the first look to the design.

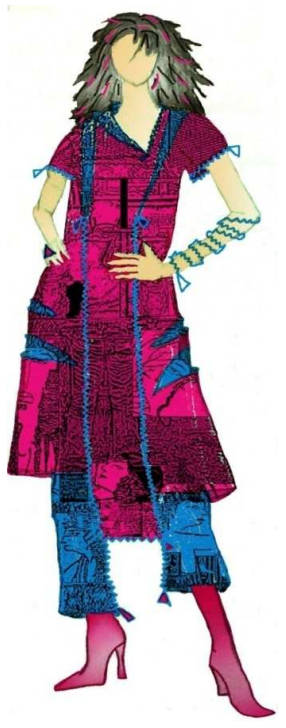

Figure (20-b) inspired structural design (fashion design)
The dress shows an interaction between decorative design and structure design. The tank man controlled on fuchsia area in dress and women take turquoise area in it. The zipper connects between parts, make good proportion to decorative design to work well together and move eyes up and down in all design.

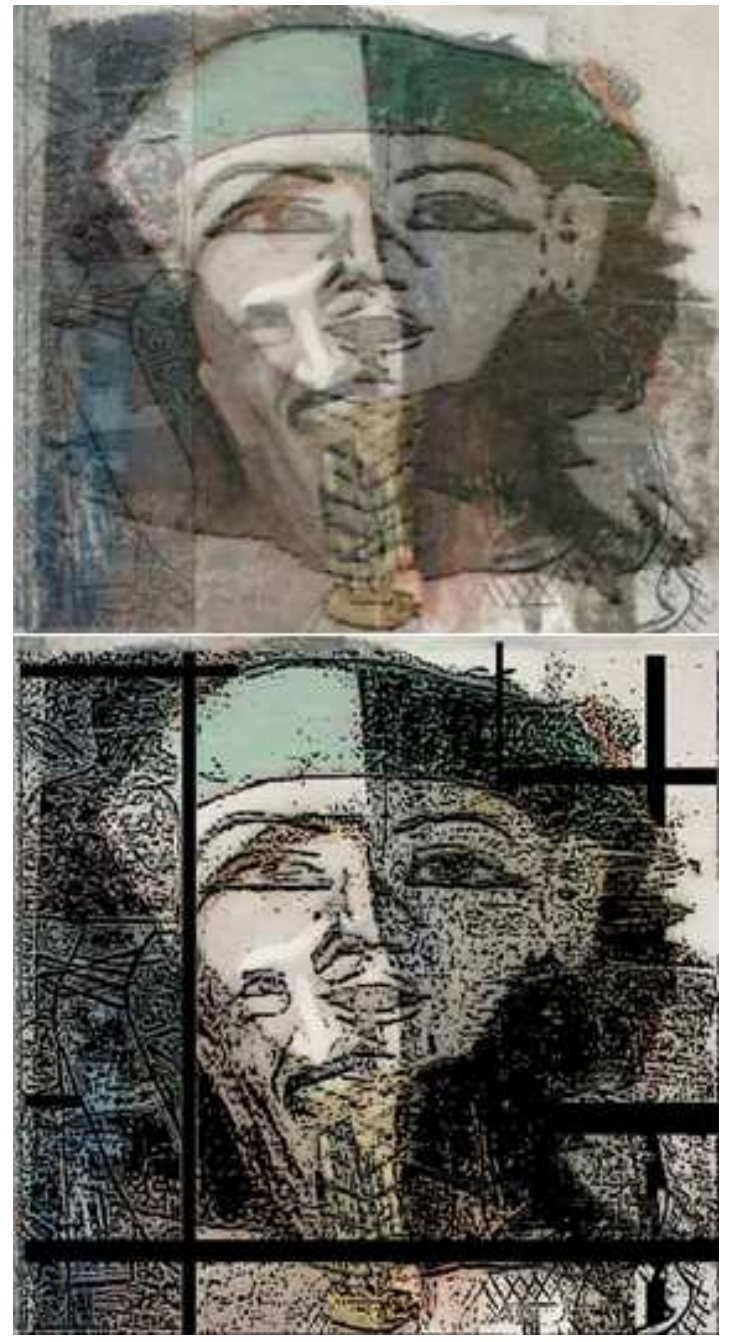

Figure (21-a) inspired decorative design (textile printing design)

The design elements include faces from figures [2b, 3b] and Hittites from fig. [11]. The two faces are in the center of the design to make balance, and longevity. Usage Hittites man in lift side not appears enough beside revolution faces to make harmony between good and evil. The designer present two editions for design, first one merge the faces and second one usage black tones to focus the faces with emphasis by bold horizontal and vertical lines like net to imprisoned enemy (Hittites man). 


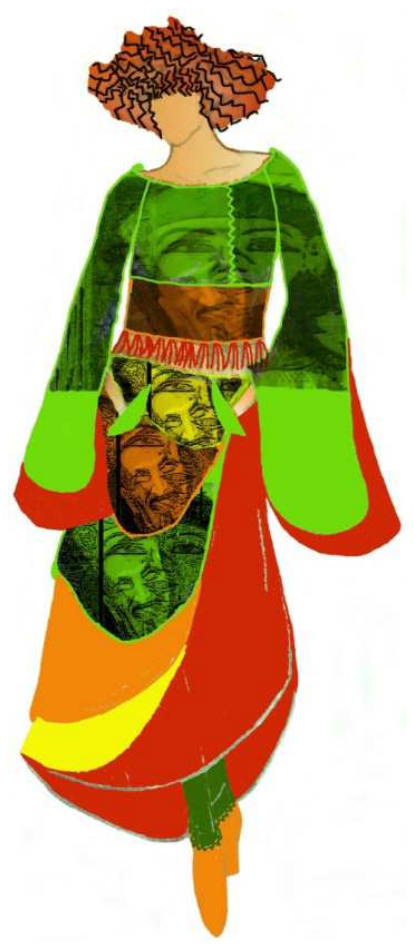

Figure (21-b) inspired structural design (fashion design)

The design contain blouse and layers skirt. The upper part shows an interaction between decorative designs but in the lower part. Different sizes of faces interacted together vertically in layers skirt to give a sense of the complete view and the life scenery. From this gradation the faces in decorative design from upper to lower part in structure design to make smooth sequence and usage hot colours from yellow, orange, red, green by the same style.

\section{Conclusion}

This research try to highlight the idea that, Egyptian revolution as universal phenomenon is still able to be approached and handled with peoples who have links to pharaonic traditions and familiarity with Egyptian land itself. The research also try to ensure the idea that, Memorial Egyptian revolution with its characteristic features have the Potential to be a vital source suitable for the field of printing designs and fashion design reflect
Egyptian loyalty to folk art.

\section{References}

[1] Ibrahim Abrash. Revaluation in Arab world, Dar ElGandi publication, March 2011.

[2] Tharwat Okasha. Ancient Egyptian art - art history: Ear, eye hear Terry - architecture, the first part, 2 edition, Family library, 2005.

[3] Jadaliyya's.Egypt's Three Revolutions: The Force of History behind this Popular Uprising, Jadaliyya's publication, 2012.

[4] wikipedia. org. Egyptian Revolution of 1919 Source, http://en.wikipedia.org/w/index.php?oldid=441445940, Dec., 2012.

[5] www.sis.gov.eg. Arab Story, http://www.sis.gov.eg/Ar/Story.aspx?sid=3258, General Authority for Information, 2013.

[6] F. William Engdahl. Egypt's Revolution:Creative Destruction for a 'Greater Middle East'?, Creative Destruction Washington Style,February 5, 2011.

[7] Ahmed Zaid. Egyptian woman and revolution, http://www.ahram.org.eg/The-Writers/News/138121.aspx, Mar., 2012.

[8] Rami El-Amine and Mostafa Henaway. A People's History of the Egyptian Revolution, Left Turn magazine, July 7, 2011.

[9] Zeitouna. Wall talk graffiti of the Egyptian revolution, zeitouna, Egypt, 2012.

[10] Wikipedia. Che Guevara,http://en.wikipedia.org/wiki/Che_Guevara, 2013.

[11] Wikipedia. V for Vendetta, http://en.wikipedia.org/wiki/V_for_Vendetta_(film), 201303-09.

[12] Gemy Hood. Battle Qasr al-Nil Bridge, http://www.gemyhood.com/2011/02/blog-post_05.html, 25-2011.

[13] Wikipedia. Egyptian tank man, http://en.wikipedia.org/wiki/Egyptian_Tank_Man, 2013-0309. 